\title{
THE THOUSAND AND ONE CHURCHES
}




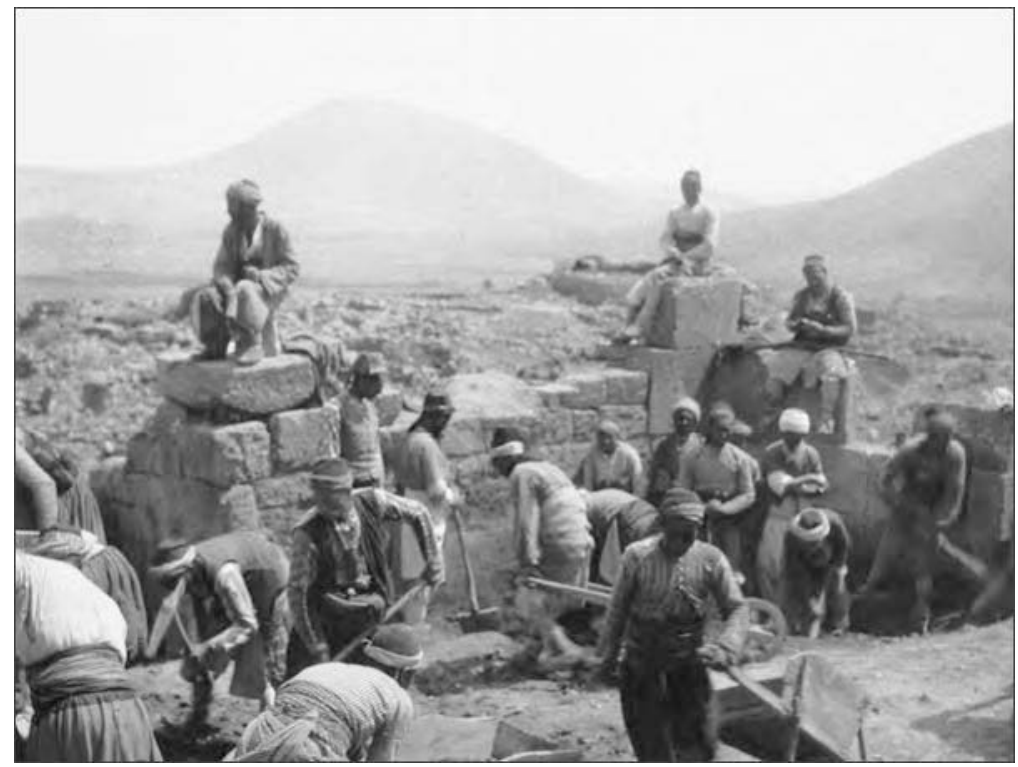

Workers at Church no. 15 at Madenşehir, May-June 1907. (Photo: Gertrude Bell Archive, H-048) 


\title{
The Thousand and One Churches
}

\author{
BY \\ SIR W. M. RAMSAY \\ AND \\ MISS GERTRUDE L. BELL
}

Foreword by Robert G. Ousterhout \& Mark P.C. Jackson

UNIVERSITY OF PENNSYLVANIA MUSEUM OF ARCHAEOLOGY AND ANTHROPOLOGY PHILADELPHIA 
Editors' Foreword (C) 2008 by University of Pennsylvania Museum of Archaeology and Anthropology, 3260 South Street, Philadelphia, PA

All Rights Reserved

Publication of this book has been generously supported by a grant from The Joukowsky Family Foundation.

Unless otherwise specified, all images are the property of Newcastle University, Newcastle upon Tyne, UK, Gertrude Bell Archive. www.gerty.ncl.ac.uk/

First published by Hodder and Stoughton, New York and London, 1909.

ORIGINAL DEDICATION

To Professor Josef Strzygowski

whose book "Kleinasien ein Neuland der Kunstgeschichte" was our constant companion during many weeks at Maden Sheher.

\section{LIBRARY OF CONGRESS CATALOGING-IN-PUBLICATION DATA}

Ramsay, William Mitchell, Sir, 1851-1939.

The thousand and one churches / by W.M. Ramsay and Gertrude L. Bell ; foreword by Robert G. Ousterhout \& Mark P.C. Jackson.

p. $\mathrm{cm}$.

Originally published: London : Hodder and Stoughton, 1909.

Includes bibliographical references and index.

ISBN 978-1-934536-05-6 (hardcover : alk. paper)

1. Architecture, Early Christian-Turkey--Konya. 2. Church architecture--

Turkey--Konya. 3. Christian antiquities--Turkey. 4. Turkey--Antiquities. I. Bell, Gertrude Lowthian, 1868-1926.. II. Title.

NA5871.K66R36 2008

726.509564--dc22

2008025328

Printed in the United States of America on acid-free paper. 